\title{
Experience of Non-Muslim Consumers on Halal as Third Party Certification Mark in Malaysia
}

\author{
Siti Hasnah Hassan ${ }^{1} \&$ Haslenna Hamdan ${ }^{1,2}$ \\ ${ }^{1}$ School of Management, Universiti Sains Malaysia, Penang, Malaysia \\ ${ }^{2}$ Faculty of Business Management, Universiti Teknologi MARA Terengganu, Terengganu, Malaysia \\ Correspondence: Haslenna Hamdan, School of Management, Universiti Sains Malaysia, 11800 Penang, Malaysia. \\ E-mail: has@tganu.uitm.edu.my; haslenna75@gmail.com
}

Received: July 8, 2013 Accepted: September 2, 2013 Online Published: October 29, 2013

doi:10.5539/ass.v9n15p263

URL: http://dx.doi.org/ass.v9n15p263

\begin{abstract}
Consumers become more concerned about the products they consume as they become aware of the benefits of third-party certification marks on product packaging and advertisements. Consumers look for food product packaging that includes information such as GMO free, organic, eco-friendly, country of origin or religiously based labels, such as kosher and Halal. This study examined the impact of a Halal certification mark as both an advertisement and a signifier of third-party certification for non-Muslims in Malaysia. The results show that non-Muslims do not think that advertisement with Halal certification mark is offensive. Structural equation modeling (SEM) analysis shows that sensitivity toward advertisement is positively related to attitudes toward advertisements, and that attitudes toward advertisements have a significant and positive relationship with behavioral outcomes. These findings enhance understanding of the effect of advertisement with Halal certification mark on non-Muslim consumers in Malaysia.
\end{abstract}

Keywords: third party certification mark, Halal, Malaysia

\section{Introduction}

Quality labels, certification marks and seals of approval have become a global trend as consumers become more ethical, greener or more health conscious and their concerns about the food risks and safety increase. Consumers look for food packaging that includes information such as GMO free, organic, eco-friendly, country of origin or vegan. Some consumers look for religiously based labels, such as kosher or Halal, that are produced with certain religious standards. Phelps (1949) defined certification marks and quality labels as "marks used upon or in connection with the products and services of one or more persons to certify regional or other origin, material, mode of manufacture, quality, accuracy, or other characteristics of such goods or services" (500).

According to Laric and Sarel (1981), the information provided by third-party certification marks may be classified into three major categories: warranty certification, evaluation certification, and factual certification. Warranty certification occurs when the certifier takes limited responsibility regarding the consumer's purchase of a given product. In evaluative certification, the certifier presents evaluative opinions in the form of either rating points or, more simply, an indication of approval or disapproval. Factual certification aims to provide factual assurance about the product's quality to the consumer. These certification marks function as general aids at the time of purchase (Taylor, 1958; Beltramini \& Stafford, 1993), protective evaluations (Laric \& Sarel, 1981) and unbiased product information (Bennett \& McCrohan, 1993).

Research interest on quality labels is growing, but the impact of these quality labels on consumers' decision making remains unclear within the marketing literature (Moussa \& Touzani, 2008). Limited studies have examined the unintended effect of quality labels, such as religiously based certification marks (Halal or kosher), on non-targeted consumers. Therefore, the aim of the present paper is to examine the impact of Halal certification marks on non-Muslim consumers in Malaysia's multicultural society. The purpose of Halal certification marks in advertisements or on product packaging is to target Muslim consumers. Few studies have examined the effect of Halal certification on non-Muslim consumers (Golnaz, Zainalabidin \& Nasir, 2012; Hassan et al., 2009).

Malaysia is a plural multi-ethnic nation in which each ethnic group maintains a distinct identity and culture 
(Freedman, 2001). However, as a multicultural nation, non-Muslim consumers live side by side with Muslim consumers. Living in close proximity is an important part of fostering interaction and reducing isolation between different ethnic groups (Tan, 1982). The Malaysian environment fosters strong social interaction in schools, colleges and workplaces. These interactions are an important way of promoting inter-ethnic relationships and ensuring mutual understanding and respect. In contrast, a lack of interpersonal interaction tends to reinforce stereotypes and hostility at the group level (Tan, 1982). Malaysia is a rare example of a plural society in which different ethnic groups accommodate each other without losing their own identities.

Although producers and businesses in Malaysia previously focused on Halal signage for food products, many non-food products (e.g., toothpaste, cosmetics, personal hygiene \& detergents) have recently included Halal certification in their advertisements. This is a new strategy by many fast moving consumer good (FMCG) companies to gain the confidence of both Muslim and non-Muslim consumers.

\section{Background}

Halal and quality certification accreditation is gaining attention among food producers as it becomes an important way of increasing companies' competitiveness in the global market. The rapid global growth of Halal recognition as a benchmark for safety and quality assurance presents a new market opportunity that meets the needs of the Muslim consumer market. Muslim consumers feel confident about purchasing such products without the need to question their authenticity. Halal can also be seen as a quality indication for non-Muslim consumers. For Muslim consumers, Halal foods and drinks suggest that these products have met the requirements established by Islamic law, also known as Shariah law, whereas for non-Muslim consumers, Halal represents a symbol of product quality and safety under the Total Quality Management of the Halal Certification System.

Halal originates from an Arabic phrase that means allowed or permitted by Islamic law and it is a term that encompasses all of a Muslim's life. In the context of food consumption, the term indicates that a particular food is permissible to be consumed. A product with Halal certification is deemed suitable for Muslim consumers. The Halal certification mark represents a high level of hygiene, cleanliness, safety, and nutrition and production under the strict requirements of Islamic dietary law. Halal foods are visually similar to other foods but are distinguished by their nature, processing, ingredients, handling and slaughter techniques (Canadian Council of Muslim Theologians, 2007). Haram foods are prohibited foods that include pig meat and pig by-products, animals that were improperly slaughtered or dead before slaughtering, animals killed in the name of anyone other than Allah, alcohol and intoxicants, carnivorous animals, birds of prey, land animals without external ears, blood and blood by-products, and foods containing any of the above. There are nine levels of food between Halal and Haram, including Makrooh and Mashbooh (Eliasi \& Dwyer, 2002), meaning doubtful or questionable products. These categories include foods containing ingredients such as gelatin, enzymes and emulsifiers.

The Halal trademark is an important marketing tool in the international arena, particularly if a product is intended to penetrate large Muslim segments of the population. Certified Halal products are accepted domestically, and they open the door to marketing products globally. The size of the Muslim market worldwide is estimated to be about two billion consumers, and $27.5 \%$ of this population is from Asia (Kettani, 2010). The Halal food market has grown over the past decade and is now worth an estimated $\$ 632$ billion per year. This number is expected to increase dramatically by the year 2020. Producers who have Halal certification can potentially gain a large segment of potential customers from local and international markets. The existence of such a large, segmented, and reachable Muslim market offers significant opportunities for businesses (Turcsik, 2001).

In Malaysia, efforts were undertaken by the government to develop the country as a potential international Halal food hub, as established in the Third National Agricultural Policy (NAP3), 1998-2010 (Othman \& Sungkar, 2009). In 2006, the Halal Industry Development Corporation (HDC) was established by the Malaysian government to develop and coordinate the national Halal industry. In an effort to attract food producers to participate in the Halal industry, incentives were introduced, such as tax deductions for ten years on capital expenditures for obtaining Halal certification and exemption from import duties and sales tax on equipment for logistical purposes.

Although the Halal market constitutes a very focused and specific market segment worldwide, there is also a potential market among non-Muslim consumers for Halal products as these consumers become aware of the high standards associated with the Halal Certification System. Certification from third-party verification can increase consumer confidence and improve the perceived quality of a product. 


\subsection{Halal as a Third-Party Certification Mark}

A certification trademark differs from an ordinary trademark because they function as a warranty that goods or services have particular characteristics. In the 1994 United Kingdom's Trademark Act, Section 50(1) of the Act defined a certification mark as follows:

"A certification mark is a mark indicating that the goods and services in connection with which it is used are certified by the proprietor of the mark in respect of origin, material, mode of manufacture of goods or performance of services, quality, accuracy or other characteristics."

Halal marks can be viewed by consumers as a form of third-party endorsement by the government and other key Islamic accreditation agencies. The Halal certification awarded by established Islamic Councils indicates authoritative, reliable support for food manufacturers' claims that their products meet strict Halal requirements under Shariah law. The Halal certificate provides assurance of the factual dimension, an evaluative opinion of the approval of the safety of the food for consumption, and an implicit warranty or guarantee of the quality of the endorsed products (Hassan et al., 2009). In Malaysia, Halal accreditation is ISO compliant (MS1500:2004), which can provide a competitive edge for companies and marketers.

Halal and quality certification accreditation is becoming increasingly important in enhancing the competitiveness of companies in the global market. Food products that are certified Halal are not only accepted domestically but are marketable to Halal consumers worldwide, creating an opportunity for export markets. Thus, a Halal certificate contributes to meeting an importing country's trade entry requirements for a Muslim market, which may enhance the products' marketability domestically and globally. Muslim and non-Muslim countries are accepting these opportunities and attempting to become leaders in the Halal business. The numbers of Halal certification authorities are increasing as many countries recognize the important of certification to enter Muslim market segments around the world.
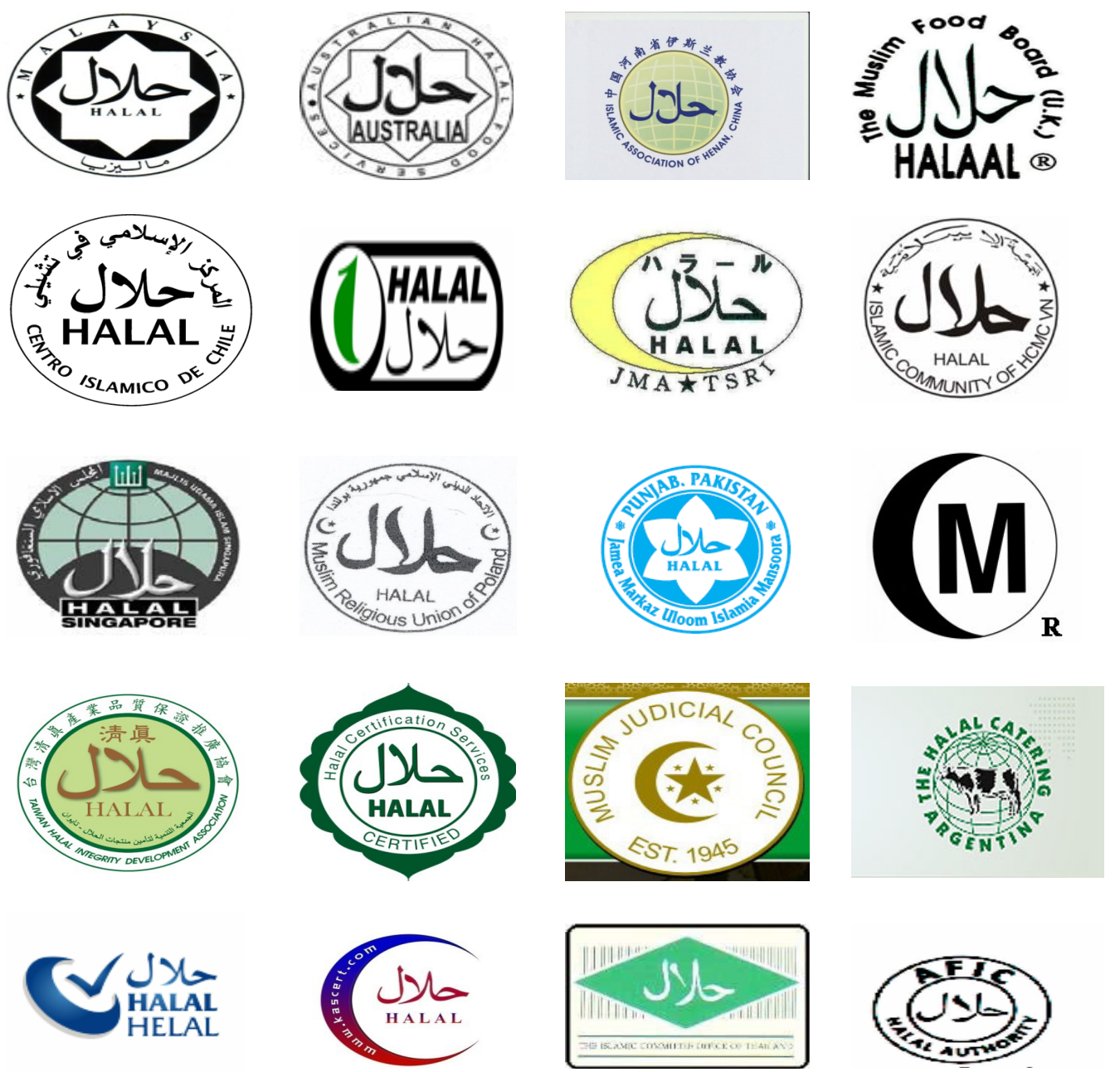

Figure 1. Example of Halal certification mark from various Islamic agencies around the world 
Figure 1 shows some example of the Halal certification symbols from various Islamic agencies around the world. In Malaysia, the Department of Islamic Development, Malaysia (DIDM), or the Jabatan Kemajuan Islam Malaysia (JAKIM), has been entrusted with the responsibility of ascertaining the Halal status of abattoirs. Halal certification can be obtained from authorized Islamic agencies. At least 57 authorized agencies are recognized by the Malaysian government. Australia has twelve authorized agencies; China, South Africa and Taiwan each have three authorized agencies; Argentina, Belgium, Brazil, the United States, India, New Zealand and Turkey each have two authorized agencies; and Austria, Bangladesh, Chile, Denmark, France, Germany, Indonesia, Italy, Japan, Pakistan, the Philippines, Poland, Singapore, Sudan, Switzerland, Thailand, the United Kingdom and Vietnam each have one authorized agency. These are just the numerous authorized agencies listed and recognized by JAKIM (JAKIM, 2011) but there are other various Islamic agencies issuing the Halal certification throughout the world.

\subsection{Consumer Food Choice and the Role of Certified Marks in Advertising}

Food choices related to values may change over time and may vary depending on factors such as gender, social class, age, education and culture (Mennell, Murcott \& Otterloo, 1992). Consumers' food choices and dietary behaviors may be markedly affected by the communication and information to which they are exposed. Communication strategies, such as advertising, are a multifaceted mechanism to inform, persuade, remind and add value to consumers (Belch \& Belch, 2011).

Consumers' food choices involve a complex process that includes a multitude of influences (Furst et al., 1996). Food is purchased on the basis of certain attributes, including taste and visual appeal, although nutritional and health value is ultimately a crucial aspect of the purchase decision (Kahle \& Kennedy, 1989). Regarding consumer food choice behavior, Grunert (2002) stated that consumers first need to form quality expectations in their purchase decision making. Quality experiences can be gained only after the product been consumed. Consumers use cues, such as smell, consistency and other visual and verbal attributes, to infer quality (Cox, 1967; Silayoi, 2007).

Attitudes include consumers' favorable or unfavorable valuations, emotional feelings and tendencies toward a product (Hawkins, Best \& Coney, 2004; Schiffman \& Kanuk, 2002). Attitudes are one of the many psychological influences that determine individual consumer behavior. Attitudes toward advertising include consumers' general liking or disliking of specific advertisements; feelings are regarded as predictors of advertising attitudes. Brand attitudes are defined as the feelings and evaluations consumers express about a specific brand (Keller, 1993). In the context of the Halal certification mark, the mark provides key attributes of spiritual and physical safety while communicating the brand's respect for Islamic principles and quality benchmarks. The presence of a Halal certification mark in an advertisement assists Muslim consumers in their purchase decisions for particular products. At the same time, companies that produce such advertisements are seen as accommodating the Muslim market, which improves their brand image among Muslim consumers because the Halal certification mark can be classified as a factual certification that assists Muslim consumers in their purchase decisions (Hassan et al., 2009). However, non-Muslim consumers will see these advertisements differently. This study examined the impact of Halal certification marks as both advertisements and as signifiers of third-party certification marks for non-Muslim consumers. The presence of a Halal certification mark may pre-dispose consumers to have favorable or unfavorable attitudes toward a product or advertisement.

\section{Methodology}

The survey instrument was developed using existing measurements from the advertising and marketing communication literatures on measures such as company credibility (Coulson, 1980; Newell \& Goldsmith, 2001), company image (Annan, 1999; Fombrun, 1996; Gray, Armstrong \& Farley, 2003), perceived sensitivity (Koslow, Shamdasani \& Touchstone, 1994), attitude toward the company (Gregory, Munch \& Peterson, 2002; Simard, Taylor \& Giles, 1976), attitude toward advertisements (Ford, LaTour \& Henthorne, 1995) and advertising targets (Koslow, Shamdasani \& Touchstone, 1994). For all measures, a 7-point Likert type scale was used, with anchors ranging from strongly agree (1) to strongly disagree (7).

The advertisement was designed by a professional advertising agency to appear similar to a realistic Malaysian print advertisement. A fictional brand of roasted chicken was chosen to minimize bias from consumers' history with the brand and to ascertain the importance of Halal as an influence in the absence of prior knowledge of the brand. The use of the new brand reduced the risk of contamination in the decision process because the existing Halal status of an established brand may be known by the respondents. The Halal mark and the word Halal were placed at the bottom of the message.

Data were gathered by survey administration teams using a non-probability sampling method of convenience 
sampling from attendees at a series of government-sponsored seminars. No selection for gender, ethnicity or age was undertaken during the data collection. A total of 246 responses were used in the subsequent analysis.

\section{Analysis and Results}

The respondents in this study consisted of 246 Malaysian non-Muslim consumers of various ethnicities and religious beliefs. Of the respondents, $37.4 \%$ were Buddhist, $56.9 \%$ were Christian, $2.4 \%$ were Hindu and $3.3 \%$ were non-believers. In terms of gender, $52.4 \%$ of the respondents were male, and $47.6 \%$ were female; $47.8 \%$ of the respondents were between 18 and 25 years old, 25.2\% were between 26 and 34 years old, 18.7\% were between 36 and 45 years old and $8.1 \%$ were 46 years old or above.

Table 1. Consumer response toward the offensiveness of the advertisement

\begin{tabular}{llll}
\hline Item & Response & Frequency & Percent \\
\hline $\begin{array}{l}\text { Do you think the presented advertisement with the Halal Strongly Disagree } \\
\text { certification mark is offensive? }\end{array}$ & Slightly Disagree & 61 & 24.8 \\
& Disagree & 65 & 22.4 \\
& Neutral & 46 & 26.4 \\
& Agree & 7 & 2.8 \\
& Slightly Agree & 6 & 2.4 \\
& Strongly Agree & 6 & 2.4
\end{tabular}

Table 1 summarizes the non-Muslim responses to the advertisement with Halal certification mark. Approximately 181 (73.6\%) non-Muslim consumers (mean score of 2.70) said that the advertisement with the Halal certification mark was offensive. We can conclude that the majority of non-Muslim consumers disagree that advertising with the Halal certification mark is offensive to them.

Table 2. List of health-related behavior measure

\begin{tabular}{|c|c|c|c|c|}
\hline Items & $\begin{array}{l}\text { Factor } \\
\text { Loading }\end{array}$ & AVE & $\begin{array}{l}\text { Composite } \\
\text { Reliability }\end{array}$ & $\begin{array}{l}\text { Cronbach's } \\
\text { Alpha }\end{array}$ \\
\hline \multicolumn{5}{|l|}{ Advertisement sensitivity } \\
\hline Q1. Advertisement is easy to understand & 0.78 & \multirow{3}{*}{0.669} & \multirow{3}{*}{0.855} & \multirow{3}{*}{0.859} \\
\hline Q2. Good advertisement & 0.94 & & & \\
\hline Q3. Advertisement was aimed at me & 0.76 & & & \\
\hline \multicolumn{5}{|l|}{ Behavioral outcome } \\
\hline Q15. I like this advertisement & 0.82 & \multirow[t]{2}{*}{0.672} & \multirow[t]{2}{*}{0.804} & \multirow[t]{2}{*}{0.864} \\
\hline Q17. Will buy product/brand & 0.82 & & & \\
\hline \multicolumn{5}{|l|}{ Attitude toward ad and brand } \\
\hline Q19. Advertisement is distinctive & 0.78 & \multirow{5}{*}{0.671} & \multirow{5}{*}{0.910} & \multirow{5}{*}{0.918} \\
\hline Q21. Advertisement is informative & 0.77 & & & \\
\hline Q22. Recommending to others & 0.81 & & & \\
\hline Q24. Advertisement is interesting & 0.88 & & & \\
\hline Q25. Brand is good & 0.85 & & & \\
\hline
\end{tabular}


The multivariate analysis was conducted using SPSS version 17 and AMOS 18. Table 2 shows the reliability measures for each item that make up the constructs used in structural equation modeling (SEM). As shown in Table 2, all item loadings exceeded 0.7; the AVE was higher than 0.5 and the composite reliability values were above 0.7 , which means that convergent validity has been established (Fornell \& Larcker, 1981).

Table 3. Regression weights for the relationship between advertisement sensitivity, attitude toward advertisement and company credibility

\begin{tabular}{|c|c|c|c|c|c|c|}
\hline Path & & & $\begin{array}{l}\text { Standardized } \\
\text { Coefficient }(\beta)\end{array}$ & $\begin{array}{l}\text { Standard } \\
\text { error }\end{array}$ & t-value & $\mathrm{P}$ \\
\hline $\begin{array}{l}\text { Advertisement } \\
\text { Sensitivity }\end{array}$ & $\rightarrow$ & $\begin{array}{ll}\text { Attitude } & \text { toward } \\
\text { Advertisement }\end{array}$ & .791 & .073 & 10.975 & $* * *$ \\
\hline $\begin{array}{l}\text { Advertisement } \\
\text { Sensitivity }\end{array}$ & $\rightarrow$ & Behavioral outcome & .080 & .079 & 1.129 & .259 \\
\hline $\begin{array}{l}\text { Attitude } \\
\text { Advertisement }\end{array}$ & toward $\rightarrow$ & Behavioral outcome & .872 & .101 & 9.637 & $* * *$ \\
\hline
\end{tabular}

Table 3 shows the path relationships between endogenous and exogenous constructs namely advertising sensitivity and attitude towards advertising (which is the IV or predictors) and behavioral outcome which are the element (DV) of study. Among the two predictors attitude towards advertisement was found to have a greater direct impact $(\beta=0.872, \mathrm{t}=9.637, \mathrm{p}<0.001)$ on behavioral outcome while no direct impact of advertisement sensitivity were found in this empirical analysis $(\beta=0.80, \mathrm{t}=1.128, \mathrm{p}>0.05)$ on behavioral outcome. Advertisement sensitivity $(\beta=0.791, \mathrm{t}=10.98, \mathrm{p}<0.001)$ is observed to indirectly impacting behavioral outcome via another independent variable tested in this study, which is attitude towards advertisement.

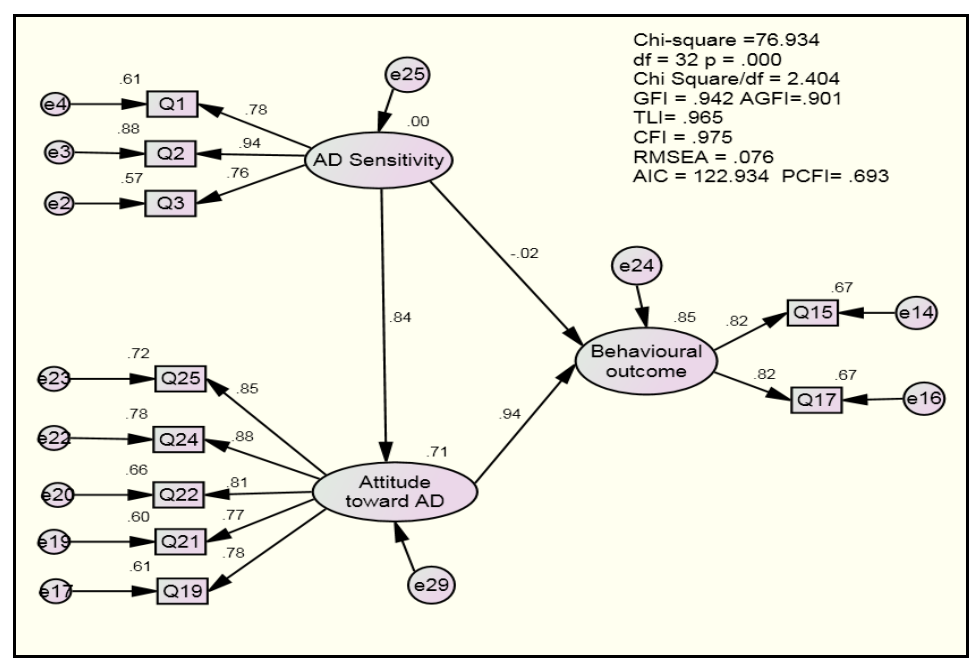

Figure 2. SEM analysis model for advertisement with Halal certification mark

Figure 2 presents the AMOS output of the relationship between the sensitivity of the advertisement, attitudes toward the ad and company credibility for non-Muslim consumers. The $\chi 2 / \mathrm{df}$ was 2.404 , below 3 , and the RMSEA $=0.076$, well within the recommended range of acceptability. Thus, the model fits the data well. The $\mathrm{CFI}=0.975$, TLI $=0.965$ and AGFI $=0.901$, all at the desired levels, further supporting the goodness of fit. In examining the relationships between the sensitivity of the advertisement with Halal certification and attitudes toward the advertisement, the sensitivity of the advertisement was positively related to attitudes toward the advertisement, $\mathrm{p}<0.001, \mathrm{R} 2=0.71$. The sensitivity of the advertisement was found to not have a significant relationship with behavioral outcomes but rather to indirectly affect behavioral outcomes through attitudes toward the advertisement. In contrast, attitudes toward the advertisement had a significant and positive relationship with behavioral outcomes. 


\section{Discussion and Implication}

This study enhanced understanding of the effect of advertising with the Halal certification mark as a quality benchmark for non-Muslim consumers in Malaysia. This study contributes to the field of advertising, especially in terms of the impact of using religiously based advertising. However, the findings of this study must be understood within the context of the country in which the study was conducted. Muslims are the dominant group in Malaysia (Invest East, 2007). As such, their reactions are based on a dominant group schema, whereas non-Muslims act based on a non-dominant group schema (Brumbaugh, 1995, 2002).

In Malaysia, non-Muslims do not find the Halal certification mark offensive because of their familiarity with the certification mark. Halal certification is an integral part of the food industry's regulatory framework in Malaysia. Non-Muslims, as a minority group, compose $45 \%$ of the population in Malaysia. They understand and react positively toward the use of Halal certification, although Halal certification marks are not a major decision-making factor when non-Muslims decide to purchase a particular product.

Managers should focus on and exploit the overall positive attitudes toward Halal certification mark in advertisements in Malaysia and other multicultural nations with significant Muslim populations. The Halal certification mark may be seen as a religiously based advertisement, especially in minority Muslim countries. In most multicultural societies, however, non-Muslim consumers are aware of the importance of the Halal accreditation endorsement, especially for food produced by non-Muslim companies. Thus, business practitioners embrace Halal accreditation practices to accommodate Muslim consumers, who may have greater buying power than do non-Muslim consumers. It is customary in Malaysia for the small Halal certification mark to be presented on the bottom right side of the front of product packaging. The Halal certification mark can be found on almost every food product on the supermarket shelves in Malaysia, whether it is produced by local or international food producers.

This study contributes to the field of advertising, especially in terms of the impact of using religiously or ethnically based advertising. This issue is related to marketers' sensitivity to non-Muslims, the unintended effects of targeting, and the reaction of dominant versus non-dominant groups to such efforts (Run, 2005, 2007). In many countries, Muslim cultures co-exist with non-Muslim cultures. In some countries where Muslims form the majority, there is likely to be a set of regulations that require food producers to be sensitive to Muslims' religious requirements. However, where the majority of the population is non-Muslim, the reaction might be different.

In multicultural nations, the Halal certification mark can be seen as a quality benchmark. Some non-Muslim consumers in Malaysia understand the Halal principles required for the production of certain products. Products with the Halal accreditation endorsement must meet certain standards to be granted certification. Therefore, Halal certification is a marketing tool that can create value by providing a message about the quality and safety of the product and by delivering value, such as trustworthy information to assist in informed decision making (Rice \& Al-Mossawi, 2002). To this end, by communicating a safety message, Halal certification can add value for consumers and marketers alike because the Halal mark indicates that the food is both physically and spiritually safe for consumption.

One limitation of this paper is its ability to generalize the results from Malaysia to other countries with different population demographics. The results may not be applicable if Muslim consumers are the minority. In Malaysia, it is believed that non-Muslims do not find Halal certification signage offensive because they are familiar with these signs. Therefore, the reactions of non-Muslims in other situations, such as when they are the majority, should be explored.

The reaction of non-Muslims in other situations or in other countries is expected to be different from the results of this study because the reactions of non-Muslim consumers to the use of Halal signs on products sold to both Muslim and non-Muslim markets when Muslim consumers are the minority have not been scientifically determined. Halal certification marks may be perceived as offensive by non-Muslim consumers from certain countries, who may see Halal certification marks as religiously based advertisements to accommodate only Muslim consumers or as religious propaganda.

Halal businesses and authorized parties for Halal certification should continuously uphold the integrity of Halal principles to avoid any distortion or negative perception regarding products with Halal marks, which are currently perceived by some non-Muslim consumers as having value-added attributes for consumption. Creating awareness of the value-added benefits of Halal certification marks for food and non-food products (such as personal care or cosmetics) is important for the success of Halal products. 


\section{References}

Annan, F. (1999). Does participation in sponsorship improve corporate image? Commerce, University of Otago, Dunedin.

Belch, G. E., \& Belch, M. A. (2011). Advertising and Promotion. Edited by I. Edition (9th ed.). U.S.A: Irwin/McGraw Hill.

Beltramini, R. F., \& Stafford, E. R. (1993). Comprehension and Perceived Believability of Seals of Approval Information in Advertising. Journal of Advertising, XXII(3), 3-13. http://dx.doi.org/10.1080/00913367.1993.10673407

Bennett, J. T., \& McCrohan, K. F. (1993). Public Policy Issues in the Marketing of Seals of Approval for Food. Journal of Consumer Affairs, 27(2), 397-415. http://dx.doi.org/10.1111/j.1745-6606.1993.tb00755.x

Brumbaugh, A. M. (1995). Managing Diversity: A Cultural Knowledge Approach to Communicating to Multiple Market Segments. PhD, Duke University.

Brumbaugh, A. M. (2002). Source and Nonsource Cues in Advertising and their Effects on the Activation of Cultural and Subcultural Knowledge on the Route to Persuasion. Journal of Consumer Research, 29(2), 258-269. http://dx.doi.org/10.1086/341575

Canadian Council of Muslim Theologians. (2007). Halal Guidelines 2007 [cited 23 Jul 2007]. Retrieved from http://www.jucanada.org/halalguidelines.html

Coulson, R. (1980). Corporate credibility: What it's all about. Business Quarterly, 45(1), 71.

Cox, D. F. (1967). Risk Taking and Information Handling in Consumer Behavior. Cambridge, MA: Harvard University Press.

Eliasi, J. R., \& Dwyer, J. T. (2002). Kosher and Halal: Religious observances affecting dietary intakes. Journal of the American Dietetic Association, 102(7), 911-913. http://dx.doi.org/10.1016/S0002-8223(02)90203-8

Fombrun, C. J. (1996). Realizing value from the corporate image. Boston, MA: Harvard Business School Press.

Ford, J. B., LaTour, M. S., \& Henthorne, T. L. (1995). Perception of Marital Roles in Purchase Decision Processes: A Cross-Cultural Study. Journal of Academic Marketing Science, 23(2), 120-131. http://dx.doi.org/10.1177/0092070395232004

Freedman, A. L. (2001). The Effect of Government Policy and Institutions on Chinese Overseas Acculturation: The Case of Malaysia. Modern Asian Studies, 35(2), 411-440. http://dx.doi.org/10.1017/S0026749X01002050

Gregory, G. D., Munch, J. M., \& Peterson, M. (2002). Attitude Functions in Consumer Research: Comparing Value-Attitude Relations in Individualist and Collectivist Cultures. Journal of Business Research, 55(11), 933-942. http://dx.doi.org/10.1016/S0148-2963(01)00213-2

Grunert, K. G. (2002). Current issues in the understanding of consumer food choice. Trends in Food Science \&amp; Technology, 13(8), 275-285. http://dx.doi.org/10.1016/S0924-2244(02)00137-1

Hassan, S. H., Kamal, K. A. M., Dann, S., \& Run, E. C. D. (2009). Influence of the Halal Certification Mark in Food Product Advertisements in Malaysia. In The New Cultures of Food: Marketing Opportunities from Ethnic, Religious and Cultural Diversity, edited by A. Lindgreen and M. Hingley: Gower.

Hawkins, I. D., Best, J. R., \& Coney, A. K. (2004). Consumer Behaviour: Building Marketing Strategy (9th ed.). Boston: Mc Graw-Hill.

Invest East. (2007). An Analysis of the World Muslim population by Country / Region 2007 [cited 24 Jul 2007]. Retrieved from http://www.factbook.net/muslim_pop.php

JAKIM. (2012). List of Approved Islamic Bodies 20112011 [cited 10 February 2012]. Retrieved from $\mathrm{http}: / /$ www.halal.gov.my/v3/

Jennifer, G., Armstrong, G., \& Farley, H. (2003). Opportunities and Constraints in the Functional Food Market. Nutrition and Food Science, 33(5), 213. http://dx.doi.org/10.1108/00346650310499730

Kahle, L. R., \& Kennedy, P. (1989). Using the List of Values LOV to Understand Consumers. Journal of Consumer Marketing, 6(3), 5. http://dx.doi.org/10.1108/EUM0000000002549

Keller, K. L. (1993). Conceptualizing, Measuring and Managing Customer-Based Brand Equity. Journal of Marketing, 57(1), 1-22. http://dx.doi.org/10.2307/1252054 
Kettani, H. (2010). World Muslim Population. Paper read at 8th Hawaii International Conference on Arts and Humanities, at Honolulu, Hawaii.

Koslow, S., Shamdasani, P. N., \& Touchstone, E. E. (1994). Exploring Language Effects in Ethnic Advertising: A Sociolinguistic Perspective. Journal of Consumer Research, 20, 575-585. http://dx.doi.org/10.1086/209371

Laric, M. V., \& Sarel, D. (1981). Consumer (Mis) Perceptions and Usage of Third Party Certification Marks, 1972 and 1980: Did Public Policy Have an Impact? Journal of Marketing, 45, 135-142. http://dx.doi.org/10.2307/1251548

Mennell, S., Murcott, A., \& Otterloo, A. H. V. (1992). The Sociology of Food, Eating, Diet and Culture. London: Sage.

Moussa, S., \& Touzani, M. (2008). The perceived credibility of quality labels: a scale validation with refinement. $\begin{array}{lllll}\text { International Journal of } & \text { Consumer }\end{array}$ http://dx.doi.org/10.1111/j.1470-6431.2008.00713.x

Newell, S. J., \& Goldsmith, R. E. (2001). The development of a scale to measure perceived corporate credibility. Journal of Business Research, 52, 235-247. http://dx.doi.org/10.1016/S0148-2963(99)00104-6

Othman, P., \& Sungkar, I. (2009). Malaysia as an International Halal Food Hub: Analysis of Its Competitiveness and Potential for Meat-Based Industries. In Malaysia in Global Perspective, edited by H. Basri and H. Mitkees: Department of Malaysian Studies, Cairo University, Giza, Egypt.

Phelps, D. M. (1949). Certification Marks under the Lanham Act. Journal of Marketing, 13(4), 498-505. http://dx.doi.org/10.2307/1247789

Rezai, G., Zainalabidin, M., \& Nasir, S. M. (2012). Non-Muslim consumers' understanding of Halal principles in Malaysia. Journal of Islamic Marketing, 3(1), 35-46. http://dx.doi.org/10.1108/17590831211206572

Rice, G., \& Al-Mossawi, M. (2002). The Implications of Islam for Advertising Messages: The Middle Eastern Context. Journal of Euromarketing, 11(3), 71-96. http://dx.doi.org/10.1300/J037v11n03_05

Run, E. C. (2005). Does Targeting Really Work? The Perspective of a Dominant Group. International Journal of Business and Society, 6(1), 27-51.

Run, E. C. (2007). Ethnically Targeted Advertising: Views Of Those Not Targeted. Journal of Asia Pacific Marketing and Logistics, 19(3). http://dx.doi.org/10.1108/13555850710772932

Schiffman, L. G., \& Kanuk, L. L. (2002). Consumer Behavior (7th ed.). New Jersey: Prentice-Hall.

Silayoi, P., \& Speece, M. (2007). The importance of packaging attributes: a conjoint analysis approach. European Journal of Marketing, 41(11), 1495-1517. http://dx.doi.org/10.1108/03090560710821279

Simard, L., Taylor, D. M., \& Giles, H. (1976). Attribution processes and interpersonal accommodation in a bilingual setting. Language and Speech, 19, 374-387.

Tan, C. B. (1982). Ethnic Relations in Malaysia. In Ethnicity and Interpersonal Interaction: A Cross Cultural Study, edited by D. Y. H. Wu. Republic of Singapore: Maruzen Asia.

Tanis, F., Connors, M., Bisogni, C. A., Sobal, J., \& Falk, L. W. (1996). Food Choice: A Conceptual Model of the Process. Appetite, 26(3), 247-266. http://dx.doi.org/10.1006/appe.1996.0019

Taylor, D. A. (1958). Certification Marks-Success or Failure. Journal of Marketing, 22(July), 9-46.

Turcsik, R. (2001). Kosher and Halal: More than Just Product. Supermarket Business, 56(11), 81.

\section{Copyrights}

Copyright for this article is retained by the author(s), with first publication rights granted to the journal.

This is an open-access article distributed under the terms and conditions of the Creative Commons Attribution license (http://creativecommons.org/licenses/by/3.0/). 